\title{
Avoin korkeakoulu opiskelijoiden arvioimana
}

Asikainen, Timo. 1988. Avoin korkeakoulu opiskelijoiden arvioimana. Aikuiskasvatus 8, 4. 2225.

Artikkeli tarkastelee opiskelijoiden mielipiteiden pohjalta avoimen korkeakoulun toimivuutta opintojärjestelmänä, ammatillisen, tutkintotavoitteisen ja harrastuspainotteisen opiskelun näkökulmista. Lisäksi käsitellään avoimen korkeakoulun merkitystä yleissivistävän koulutuksen antajana, opintojärjestelmän vaikutusta koulutuksellisen tai yhteiskunnallisen tasa-arvon toteutumiseen ja avoimen korkeakoulun alueellista merkitystä. Tulosten mukaan arvosanaopetusta käytetään yhä enemmän ammatillisena täydennyskoulutuksena. Ongelmana on, että opinnot koetaan usein pelkäksi muodolliseksi ammatilliseksi lisäpätevöitymiseksi. Myös opintojen tutkintotavoitteisuus ja niiden merkitys osana muuta opiskelua on huomattava. Kokonaisuudessaan voi arvioida, että avoin korkeakoulu pystyy verraten hyvin täyttämään opiskelijoiden opintojärjestelmään kohdistuneet odotukset.

Artikkeli perustuu Tampereen yliopistossa tehtyyn aikuiskasvatuksen syventävien opintojen tutkielmaan.

Toiminnan tuloksellisuuden ja tehokkuuden perään kysellään yhä useammalla elämänalueella. Koulutuksen vaikuttavuuden tutkimus pyrkii mahdollisimman monipuoliseen tarkasteluun eikä rajoitu suppeaan koulutuksen tulosten arviointiin. Tulosajattelulle ja koulutuksen vaikuttavuuden tutkimukselle lienee kuitenkin yhteistä se, että olennaisin pelkistetään arvioinnin pohjaksi.

Pyrin avoimen korkeakouluopiskelun osallistumistavoitteita ja opiskelun koettua vaikuttavuutta käsitelleessä tutkielmassani arvioimaan myös avoimen korkeakoulun merkitystä ja toimivuutta opintojärjestelmänä eli miten hyvin avoin korkeakoulu on pystynyt täyttämään sille asetetut koulutukselliset tehtävät. Tutkimusaineisto kerättiin strukturoituja ja avoimia kysymyksiä sisältäneellä kyselyllä, jonka kohdejoukkona oli eri oppiaineissa (kasvatustiede, yhteiskuntatieteet, oikeustieteet ja humanistiset tieteet) arvosanoja v. 1983-1986 Jyväskylän yliopiston täydennyskoulutuskeskuksen Keski-Pohjanmaan täydennyskoulutusyksikössä ja Keski-Pohjanmaan kesäyliopistossa suorittaneet aikuisopiskelijat. Valitettavasti koko maan avoimen korkeakoulun opiskelijoista ei vielä tällä hetkellä ole saatavissa taustatietoja. Silti kyselyyn vastanneet 112 henkilöä (vastaamisprosentti kyselyyn oli 83,6) edustanevat sosiaalisilta ja demograafisilta taustoiltaan koko maan opiskelijakuntaa. Arvosanasuoritusten oppiaineet edustavat hyvin tä- mänhetkistä avoimen korkeakoulun toimintaa. Kasvatustieteessä arvosanan suorittaneita oli kuitenkin kohdejoukossa keskimääräistä enemmän.

Avoimen korkeakouluopiskelun osallistumistavoitteita on selvitetty useammassa tutkimuksessa jo avoimen korkeakoulun toiminnan alkuajoista, aina 1970-luvun puolivälistä lähtien. Koulutuksen vaikuttavuus on vielä uusi tutkimusalue aikuiskasvatuksessa. Sen tärkeys tulee kyllä mielestäni vakuuttavasti esille esim. Tapio Vahervan teoksessa Koulutuksen vaikuttavuus. Käsiteanalyyttista tarkastelua ja viitekehyksen hahmottelua (1983). Parhaimmillaan, ja vaativimmillaan, vaikuttavuustutkimus joutuu yhdistämään suuren joukon lähestymistapoja tutkimuskohteeseensa, eri tutkimussuuntia, niiden teorioita ja tutkimustekniikoita.

Hyvin tietoisena riittämättömistä mahdollisuuksista "täyteen" avoimen korkeakoulun vaikuttavuuden tarkasteluun, päätin käyttää osallistumistavoitteista ja opiskelun koetusta vaikuttavuudesta saatuja tuloksia avoimen korkeakoulun arviointiin opintojärjestelmänä, kokonaisuutena. Arviointi nojautuu opiskelijoiden näkemyksiin, siis opintojärjestelmän käyttäjien subjektiivisiin mielipiteisiin. Vaikuttavuuden tarkastelun kriteereinä olivat puolestaan avoimelle korkeakoululle sen suunnittelussa asetetut koulutukselliset tavoitteet (Suomen Kulttuurirahaston Avoimen korkeakoulun toimikunnan mietinnössä vuodelta 1976 ja ope- 
tusministeriön asettaman Avoimen korkeakoulun toimikunnan mietinnössä vuodelta 1981). Arviointikriteerit otettiin annettuina, eikä pyritty itse määrittelemään näkökulmia avoimen korkeakoulun merkityksen tarkastelulle. Suunnittelussa opintojärjestelmälle asetettujen tavoitteiden arvioinnilla on perusteltua, koska mietintöjen kannanotot ovat ohjanneet avoimen korkeakoulun kehittymistä.

\section{Opintojärjestelmälle asetetut tavoitteet}

Mainituissa mietinnöissä avoimen korkeakoulun tavoitteiksi määriteltiin 1. ammatillisen täydennys-, jatko- ja uudelleenkoulutuksen antaminen, 2. tutkintotavoitteisen, pohjakoulutuksesta riippumattoman korkeakouluopiskelun mahdollistaminen ja 3. yleissivistävien, väljätavoitteisten ja harrastuspainotteisten opiskelumahdollisuuksien lisääminen (Suomen Kulttuurirahaston Avoimen korkeakoulun toimikunnan mietintö 1976, 115-127; Avoimen korkeakoulun toimikunnan mietintö 1981, 26). Aikuisopiskelu voi olla yleissivistävää, olipa se tavoitteiltaan ammatillista, tutkintotavoitteista tai harrastustoimintaa. Siksi seuraavassa käsitellään avointen korkeakouluopintojen yleissivistävää merkitystä erillään harrastuspainotteisesta opiskelusta. Yleissivistävyys on tärkeä aspekti arvioitaessa avoimen korkeakoulun toimivuutta.

Avoimen korkeakoulun suunnittelussa tähdennettiin opintojärjestelmän koulutuksellista ja yhteiskunnallista tasa-arvoa lisäävää vaikutusta. Siksi tasa-arvokysymyksiä tarkastellaan erikseen. Koska tutkimusaineisto kerättiin maakunnassa, jossa ei ole korkeakoulua, voidaan käsitellä myös avoimen korkeakoulun alueellista merkitystä.

\section{Ammatillisena koulutuksena}

Arvosanaopiskelun merkitys ammatillisena jatko- ja täydennyskoulutuksena on korostunut lähes kaikissa aiemmissakin tutkimuksissa. Ei liene yllättävää, että nyt saadut tulokset osoittavat ammatillisten osallistumistavoitteiden tulleen yhä tärkeämmiksi. Lähes $70 \%$ vastaajista ilmoitti työhön liittyvät syyt opiskelulleen ensisijaisiksi tai joka tapauksessa tärkeiksi.

Arvosanaopiskelulla tahdotaan parantaa ammatillisia valmiuksia tai ymmärtää työtehtäviin liittyviä asioita laajemmin, ylipäänsä parantaa ammattitaitoa laajassa merkityksessä. Korostuneesti tuli kuitenkin esille arvosanaopiskelun merkitys muodollisena ammatillise- na lisäpätevöitymisenä ja keinona uralla etenemiselle. Yli kolmannes opiskelijoista odotti arvosanaopiskelulta tämänkaltaisia hyötyjä. Hyötyodotukset ovat kuitenkin luonteeltaan implisiittisiä, opiskellaan "kaiken varalta", vaikka ei vielä tiedetä, miten opintoja voi käyttää hyväksi työelämässä etenemisessä.

Arvioidessaan opiskelun vaikuttavuutta lähes $53 \%$ vastaajista katsoi arvosanaopiskelun lisänneen heidän ammattitaitoaan. Näin vastanneiden määrä on siis pienempi kuin niiden, jotka odottivat opiskelulta ammatillisia hyötyjä. Näyttää siltä, että osa opiskelijoista on odottanut arvosanaopiskelulta todellakin pelkkää muodollista lisäpätevöitymistä. Osa on taas aidosti pettynyt opiskelun sisältöön ammattinsa kannalta. Heidän määränsä on kuitenkin vain n. viisi prosenttia opiskelijoista. Opiskelun ammatilliseen antiin pettyneiden joukossa on niitäkin, joiden pohjakoulutustaso ja ammattiasema ovat korkeita. Heidän kohdallaan paljastuu se, että yliopistollinen perusopetus ei välttämättä pysty hyödyntämään kaikkien aikuisopiskelijoiden aikaisempia tietoja ja kokemusta.

\section{Osana muita opintoja}

Avoimen korkeakoulun tutkintotavoitteisuudella tarkoitetaan mahdollisuutta suorittaa korkeakoulututkinto aloittamalla opinnot avoimessa korkeakoulussa. Kiinnostus koulutustien käyttöön tai aikomukset pyrkiä valintakokeen kautta yliopistoon olivatkin opiskelijoiden keskuudessa yleisiä, koska yli $40 \%$ opiskelijoista tahtoi arvosanaopiskelulla tutustua oppiaineeseen mahdollisia korkeakouluopintoja varten. Yli 55 \% opiskelijoista ilmoitti arvosanaopiskelulla haluavansa parantaa jatkoopiskelumahdollisuuksiaan yleensä. Kaikkiaan avointa korkeakoulua käytetään enemmän hyväksi valintakokeen kautta tapahtuvan korkeakouluihin pääsyn helpottamiseksi tai muihin oppilaitoksiin ja erillisiin ammatillisiin koulutusohjelmiin pyrkimiseksi kuin siirtymisväylänä korkeakouluun 60 opintoviikon suorituksen jälkeen.

Avoin korkeakoulu oli tukenut myös opiskelijoiden jatko-opintoihin liittyviä tavoitteita merkittävästi, sillä yli $20 \%$ vastaajista arvioi arvosanaopiskelun auttaneen heitä opiskelupaikan hankkimisessa. Lisäksi avoimessa korkeakoulussa opiskelevista $12 \%$ oli eri oppilaitoksissa päätoimisesti opiskelevia. Avoimen korkeakoulun opinnollinen merkitys ei siis rajoitu tutkintotavoitteisuuteen. Koska opiskelijoista vain vajaa neljännes oli alle 24-vuotiaita ja keski-ikä oli 33 vuotta, voi avoimen korkeakoulun merkitystä osana opiskelijoidensa jatko- 
opiskelua pitää yllättävänkin laajana. Prosenttiluvut osoittavat, että halukkuutta jatko-opintoihin on suurella joukolla vanhemmistakin avoimen korkeakoulun opiskelijoista.

\section{Ei pelkkänä harrasteena}

Odotetusti arvosanaopiskelu pelkkänä harrasteena, ilman ammatillisia tai opinnollisia, päämääräkeskeisiä tavoitteita, ei ollut yleistä. Alle kymmenen prosenttia vastaajista piti opiskelua harrastuksen vuoksi osallistumiselleen erityisen merkityksellisenä. Humanistisissa aineissa pelkkä harrastusopiskelu oli yleisempää kuin muissa oppiaineissa. Voidaan sanoa, että avoimesta korkeakoulusta ei - nykyisellä oppiainetarjonnalla - ole tullut suuressa määrin harrastuspainotteisen opiskelun muotoa, ainakaan täydennyskoulutuskeskuksissa ja kesäyliopistoissa opiskelevien keskuudessa.

Silti opiskelun merkitystä mielekkäänä ja kehittävänä vapaa-ajan viettotapana ei ole syytä väheksyä. Esim. akateemisesti koulutetut korostivat opiskelunsa harrastusluonnetta ammatillisten tavoitteiden rinnalla. Heille asuinpaikkakunnan opiskelumahdollisuuksiin liittyy tietoisia odotuksia. Koulutettu väestö odottaa yhä parempia aikuiskoulutuspalveluja osana riittävän korkeaa yleistä palvelutasoa.

\section{Yleissivistävänä koulutuksena}

Avoimen korkeakoulun opiskelijoiden osallistumistavoitteille on tyypillistä, että päämääräkeskeisien tavoitteiden kanssa yhtäaikaisesti vaikuttavat oppimiskeskeiset, tiedolliset tavoitteet. Opiskelun yleissivistävät vaikutukset koetaan myös positiivisesti. Ensiksikin 2/3 opiskelijoista katsoi, että opiskelu oli todella lisännyt heidän yleissivistystään. Tulos on ehkä odotettu, mutta on muistettava, että vastaajien keskiikä, koulutustausta ja työkokemus olivat siksi korkeita, että opetuksen sisällölle varmasti asetettiin tietoisia odotuksia. Opiskelu on myös lisännyt aktiivisuutta ja kehittänyt kriittisyyttä asioiden seuraamisessa tiedotusvälineistẳ opiskellun oppiaineen alalta sekä lisännyt oppiaineeseen liittyvän kirjallisuuden lukemista opiskelun päätyttyä. Uutta tietoa siis käytetään myös hyväksi muutenkin kuin ammatissa ja opiskelussa.

Vaikka ammatilliset ja opinnolliset tavoitteet ovatkin tulleet yhä tärkeämmiksi avoimessa korkeakoulussa opiskeleville, ei niiden merkityksen kasvu ole tapahtunut arvosanaopiskelun yleissivistävyyden ja tiedon itseisarvoa korostavan merkityksen kustannuksella. Onkin tärkeää, ettei avoimen korkeakoulun instrumentaalisia ja yleissivistäviä päämääriä nähdä dikotomiana, jossa toisen korostuminen tietäisi toisen merkityksen vähentymistä.

\section{Tasa-arvon toteuttajana}

Avoimella korkeakoululla on pyritty toteuttamaan koulutukseen pääsyn tasa-arvoisuutta. Miten opintojärjestelmä on tässä tehtävässään onnistunut? Tehdyssä tutkimuksessa mukana olleista opiskelijoista 3,6 \%:lla oli pohjakoulutuksena peruskoulu ja vain vajaa neljännes ei ollut suorittanut ylioppilastutkintoa. Korkea-asteen koulutuksen saaneita taas oli yli neljännes opiskelijoista. Opiskelijoiden koulutustaso oli muuhun väestöön verrattuna korkea, joten pelkkä koulutukseen pääsyn mahdollisuus ei ole lisännyt koulutuksellista tasa-arvoa.

Avoin korkeakoulu kuitenkin tasoittaa koulutuksellisia eroja hyvinkoulutettujen keskuudessa antamalla työelämässä oleville, keskiasteen koulutuksen saaneille käytännön mahdollisuuden aloittaa korkean asteen opinnot. Keskiasteen tutkinnon suorittaneita olikin lähes puolet opiskelijoista. Heidän keskuudessaan tutkintotavoitteiset tai muihin jatko-opintoihin liittyvät osallistumistavoitteet olivat myös keskimääräistä voimakkaampia.

Sukupuolten välillä avoin korkeakoulu näyttää edistävän ammatillista tasa-arvoa. Naisille, vastoin aiempia tutkimuksia, olivat ammatilliset osallistumistavoitteet jopa tärkeämpiä kuin miehille. Tulos ei tietenkään vielä osoita koulutuksen lopullisia vaikutuksia työelämässä. Kuitenkin vastausten mukaan naiset - joiden asema työelämässä oli miehiä heikompi olivat paremmin pystyneet hyödyntämään opiskelunsa työelämässä etenemiseksi. Ammatillisena koulutuksena avoin korkeakoulu palvelee tällä hetkellä parhaiten naisvaltaisia työaloja. Naisia olikin tehdyn tutkimuksen vastaajajoukossa 3/4.

Avoin korkeakoulu luo myös koulutusmahdollisuuksia naisille, joiden opintojen aloittaminen on lykkäytynyt perheen perustamisen takia. Vasta lasten vartuttua he katsovat opinnot mahdollisiksi, ja silloinkin on tärkeää, että opintoja voi harjoittaa kotipaikkakunnalla. Heidän määräänsä ei kyselyn antamien tietojen perusteella voi tarkasti määritellä, mutta varsin usein avoin korkeakoulu luo mahdollisuuksia lykkääntyneiden kouluttautumistoiveden toteuttamiselle.

\section{Alueellinen merkitys}

Avoimen korkeakoulun merkitystä on varsin harvoin käsitelty koulutuksen alueellisen ja- 
kautumisen näkökulmasta, vaikka näyttää siltä, että opintojärjestelmällä on - jo siinä laajuudessa kuin sitä nykyisin esim. Keski-Pohjanmaalla toteutetaan - koulutuksellista alueellista tasa-arvoa lisäävää vaikutusta. Aiemmin on jo todettu, että $20 \%$ opiskelijoista oli käyttänyt arvosanaopiskelua hyväksi opiskelupaikan hankkimisessa. Maakunnassa, jossa ei ole korkeakoulua, ja joka on aliedustettu korkeakoulujen opiskelupaikkojen jakautumisessa, on avoimella korkeakoululla luonnollisesti tehtävänä mahdollistaa korkean asteen opinnot edes osaksi ja - ehkä vielä tärkeämpää - helpottaa opiskelupaikkaa hakevien pyrkimistä muualla korkeakouluihin ja muihin oppilaitoksiin.

Aluepoliittisesta näkökulmasta avointa korkeakoulua voidaan tarkastella osana korkeakoululaitoksen kehittämistä. Korkeakoululaitokseen kohdistuva aluepoliittinen mielenkiinto on lisääntynyt ns. innovaatio-orientoituneen aluepoliittisen paradigman myötä (Jolkkonen 1986). Paradigman mukaan on välttämätöntä kehittää eri alueiden taitotietotasoa. Alueittaisen tietoinfrastruktuurin luomisessa on hajautetulla korkeakouluverkostolla keskeinen asema. Tietenkään avoin korkeakoulu ei vaikutuksiltaan voi olla verrannollinen korkeakouluun, mutta esim. alueensa tuotantoelämää palvelevan täydennyskoulutuksen antajana se voi olla tehokaskin.

\section{Johtopäätöksiä, kritiikkiä}

Opiskelijoiden oman arvioinnin valossa avoimessa korkeakoulussa yhdistyvät verraten hyvin aikuiskoulutuksen yleissivistävät ja ammatilliset päämäärät. Mielestäni tätä on pidettävä opintojärjestelmän vahvuutena, jos arvioidaan sen asemaa elinikäisen kasvatuksen periaatteen toteuttajana aikuiskoulutusjärjestelmässä. Ammatillisten valmiuksien parantamisen rinnalla opiskelun yleissivistävyys, paitsi olemalla sinänsä opiskelijoiden arvostamaa, lisää mahdollisuuksia ja luo positiivisia asenteita muuhun, vielä pidemmällekin tähtäävään aikuiskoulutukseen.

Opiskelijat myös arvioivat aikuisopiskelumuotona avoimen korkeakoulun hyvin myönteisesti. Muihin aikuisopiskelumahdollisuuksiin verrattuna avointa korkeakoulua pidettiin tehokkaana opiskelumuotona. Lisäksi monet korostivat avoimen korkeakoulun onnistuneisuutta opintoyhteisönä. Ilmeistä onkin, että työskentelyilmapiiriltään, yhteishengeltään ja sosiaălisilta kontakteiltaan avoin korkeakoulu koetaan miellyttävänä ja opiskelua tukevana. Tämä on ainakin opintonsa loppuunsuorittaneiden mielipide. Toiminnallaan avoin korkeakoulu turvaa tulevaisuuttaan, koska yli puolet opiskelijoista tahtoi jatkaa arvosanaopiskelua.
Kriittisesti on suhtauduttava siihen, että avoin korkeakouluopiskelu koetaan helposti pelkästään keinoksi lisätä muodollista ammatillista pätevyyttä. Sinänsä muodollisen pätevyyden lisääminen koulutuksella on luonnollista, itse asiassa yliopistokoulutukselle tyypillistä. Näyttää siltä, että avoimen korkeakoulun pedagoginen kehittäminen vaatisi opiskelijoiden tietämyksen ja toiveiden parempaa huomioon ottamista opetuksessa silloin, kun opetukseen hakeudutaan ammatillisten tavoitteiden takia. Ehkä opiskelun kokeminen liiaksi pelkkänä muodollisena koulutuksena on yksi syy verraten korkeaan opintojen keskeyttämiseen avoimessa korkeakoulussa. Kaiken kaikkiaan ammatillisten tavoitteiden merkitys opiskelijoille tulisi ottaa huomioon opintojärjestelmää kehitettäessä.

Vuonna 1987 on arvioitu yleissivistävän aikuiskoulutuksen kustannuksiksi 1020 miljoonaa markkaa ja ammatillisen aikuiskoulutuksen 1370 miljoonaa markkaa (Pitkänen 1988). Voidaan arvioida, että avoimen korkeakouluopetuksen osuus yleissivistävän koulutuksen kustannuksista on runsaat viisi prosenttia. Opiskelijoita samana vuonna on Tilastokeskuksen antamien ennakkotietojen mukaan ollut n. 26500. On totta, että vielä nykyisellään avoin korkeakouluopetus on kokonaisuudessaan paljolti pelkkää yliopistollisen opetuksen välitystoimintaa. Resurssien puuttuessa ei toiminnan kehittämistyöhön ole voitu panostaa riittävästi (vrt. Taskinen 1986). Kehittämistyön nykyvaihe huomioon ottaen on kuitenkin myönteistä, että avoimen korkeakoulun opiskelijat arvioivat tämänhetkisenkin opintojärjestelmän toimivaksi.

\section{Lähteet}

Asikainen, T. 1988. Osallistumistavoitteet ja opiskelun koettu vaikuttavuus Keski-Pohjanmaalla avoimessa korkeakoulussa. Chydenius-Instituutin tutkimuksia nro 37. Kokkola.

Avoin korkeakoulu. Suomen Kulttuurirahaston avoimen korkeakoulun toimikunnan mietintö 1976 . Helsinki.

Jolkkonen, A. 1986. Suomalainen korkeakoulumalli aluekehityksen voimavarana. Sisäasiainministeriö. Aluepoliittinen osasto. Aluepoliittisia tutkimuksia ja selvityksiä 8/1986. Helsinki.

Komiteanmietintö 1981:36. Avoimen korkeakoulun toimikunnan mietintö. Helsinki.

Pitkänen, K. 1988. Funding adult education. Adult Education in Finland 1/1988, 2-7.

Taskinen, J. 1986. Avoin korkeakoulu — kymmenen vuotta kokeilua ja kiistelyä. Aikuiskasvatus 1/ 1986, 2-3.

Vaherva, T. 1983. Koulutuksen vaikuttavuus. Käsiteanalyyttistä tarkastelua ja viitekehyksen hahmottelua. Jyväskylän yliopiston kasvatustieteen laitoksen julkaisuja A 1. Jyväskylä. 


\section{AIKUISKASVATUS \\ The Finnish Journal of Adult Education \\ Vol. 8,4/88 \\ ISSN 0358-6197 \\ Summary}

Asikainen, Timo 1988. Open University as assessed by students enrolled in it.

- With the views held by students as the basis, the article looks into the functionality of the Open University as system of study, from the aspect of vocational, degree-oriented, and avocational studies. In addition, it looks at the Open University's role as an institution offering general education, at the effect of the system of study on the realization of educational and social equality, and at the regional significance of the Open University. The results indicate that degree-studies are being used more and more as vocational further education. The problem is that studies are often seen as representing a mere formal vocational further qualification. All in all, it is assumed that the Open University is fairly well able to fulfill the expectations of students regarding the system of study. 